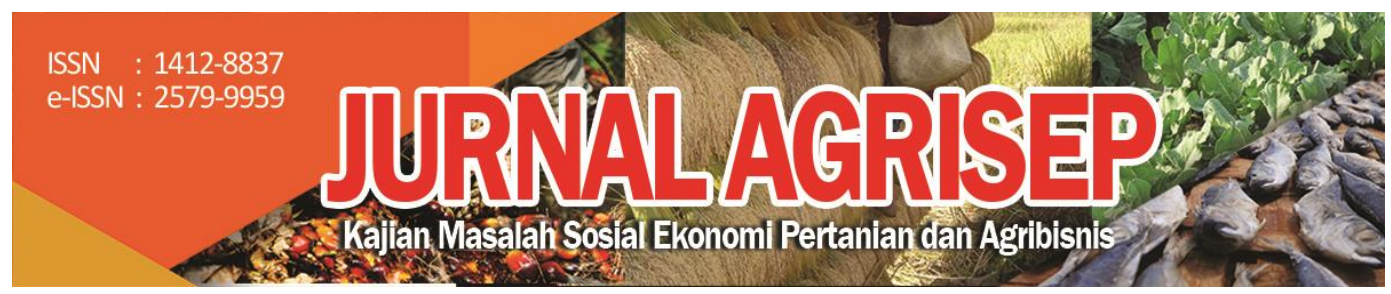

DOI: 10.31186/jagrisep.20.1.117-128

\title{
PENGARUH KOMPETENSI KEWIRAUSAHAAN TERHADAP KINERJA USAHA UMKM KOPI: SEBUAH TINJAUAN TEORITIS DAN EMPIRIS
}

\section{Effect of Entrepreneur Competency of Coffee MSME Business Theoretical and Empirical Review}

\author{
Anggita Tresliyana Suryana $\bigotimes_{1 \text { ); Burhanuddin }}{ }^{2}$
}

1) Program Studi Ilmu Ekonomi Pertanian, Institut Pertanian Bogor; Balai Besar Pengkajian dan Pengembangan Teknologi Pertanian, Badan Litbang Pertanian

2) Departemen Agribisnis, Fakultas Ekonomi dan Manajemen, Institut Pertanian Bogor e-mail : tresliyana@gmail.com

\begin{abstract}
Coffee MSMEs in Indonesia is growing with an increase in domestic coffee consumption in Indonesia. However, coffee MSME also experiences various business development problems due to entrepreneurial competencies. Further studies are needed to understand what competencies affect coffee MSME performance, so that they can develop entrepreneurial development strategies more precisely. The result of this study provides finding indicated an effect of entrepreneurial competence on the business performance of coffee MSMEs in Indonesia. In general, the variables that influence coffee UMKM entrepreneurial competencies are conceptual abilities, skills and individual characteristics. To develop the business performance of Indonesian coffee MSMEs, strategy need to be carried out is to increase the capability of coffee MSME entrepreneurs in both technical and management fields.
\end{abstract}

Keywords: competence, entrepreneurship, coffee UMKM, business performance 


\begin{abstract}
ABSTRAK
UMKM kopi di Indonesia sedang berkembang dengan adanya peningkatan konsumsi kopi di Indonesia. Namun demikian, UMKM kopi pun mengalami berbagai permasalahan pengembangan usaha akibat kompetensi wirausaha yang belum unggul. Studi ini bermaksud untuk mengkaji pengaruh kompetensi kewirausahaan terhadap kinerja UMKM kopi dan menyusun strategi pengembangan kewirausahaan UMKM Kopi yang efektif. Metode studi pustaka digunakan dengan fokus pada tinjauan teoritis dan tinjauan empiris. Hasil studi menunjukkan bahwa kompetensi kewirausahaan terbukti mempengaruhi kinerja usaha UMKM kopi di Indonesia. Secara umum, variabel yang mempengaruhi kompetensi kewirausahaan UMKM kopi adalah kemampuan konseptual, keterampilan dan karakteristik individu. Dalam rangka mengembangkan kinerja usaha UMKM kopi Indonesia, strategi yang dapat dilakukan adalah dengan peningkatan kapabilitas wirausaha UMKM kopi baik di bidang teknis dan manajemen.
\end{abstract}

Kata kunci: kewirausahaan, kompetensi, UMKM kopi, kinerja usaha

\title{
PENDAHULUAN
}

Dalam pembangunan ekonomi Indonesia, Usaha Mikro, Kecil dan Menengah (UMKM) menduduki peran yang cukup strategis dan penting. Proporsi UMKM adalah 99,99\% dari seluruh pelaku usaha nasional atau sebesar 62,9 juta unit, menyumbang sekitar 61,07\% dari total PDB (Kemenkop, 2018). Sumbangan UMKM pada PDB tersebut berasal dari agregasi beberapa sektor ekonomi, menurut Bank Indonesia (2015) diantaranya adalah sektor usahatani (pertanian, peternakan, kehutanan dan perikanan) sebesar 48,85\%; industri pengolahan sebesar 6,41\%; sektor pemasaran (perdagangan, restoran, dan hotel) sebesar 28,83\%; dan jasa pendukung (distribusi, komunikasi, keuangan, sewa, dan jasa lain) sebesar 13,77\%.

Peranan strategis UMKM dalam ekonomi Indonesia terlihat pada posisinya sebagai pelaku kunci dalam kegiatan ekonomi di beragam sektor, antara lain dalam hal penyediaan lapangan pekerjaan terbanyak, sumber inovasi, pemberdayaan masyarakat, pengembangan aktivitas ekonomi lokal, penciptaan pasar baru, maupun perdagangan internasional (Bank Indonesia, 2015).

Salah satu komoditas agribisnis yang memiliki daya tarik bagi pelaku UMKM saat ini adalah kopi. Hal ini dapat dilihat dari meningkatnya jumlah konsumsi kopi Indonesia dalam 17 tahun terakhir. Peningkatan konsumsi kopi Indonesia di dalam negeri dari 0,72 kg/kapita pada tahun 2008 menjadi 1,27 $\mathrm{kg} / \mathrm{kapita}$ pada tahun 2013 dan diprediksi sebesar 1,5 kg/kapita pada tahun 2019 (Kemenperin, 2014). Data pada Gambar 1 secara tidak langsung

118 | Anggita Tresliyana Suryana; Burhanuddin; Pengaruh Kompetensi... 
menunjukkan peningkatan permintaan kopi yang difasilitasi oleh pertumbuhan minat masyarakat menekuni usaha kopi, mulai dari pengolahan pasca panen, roasting kopi, penjualan roasted bean, hingga membuka coffee roastery maupun kedai kopi (coffee shop) (Rasyidatushshalihah, 2018).

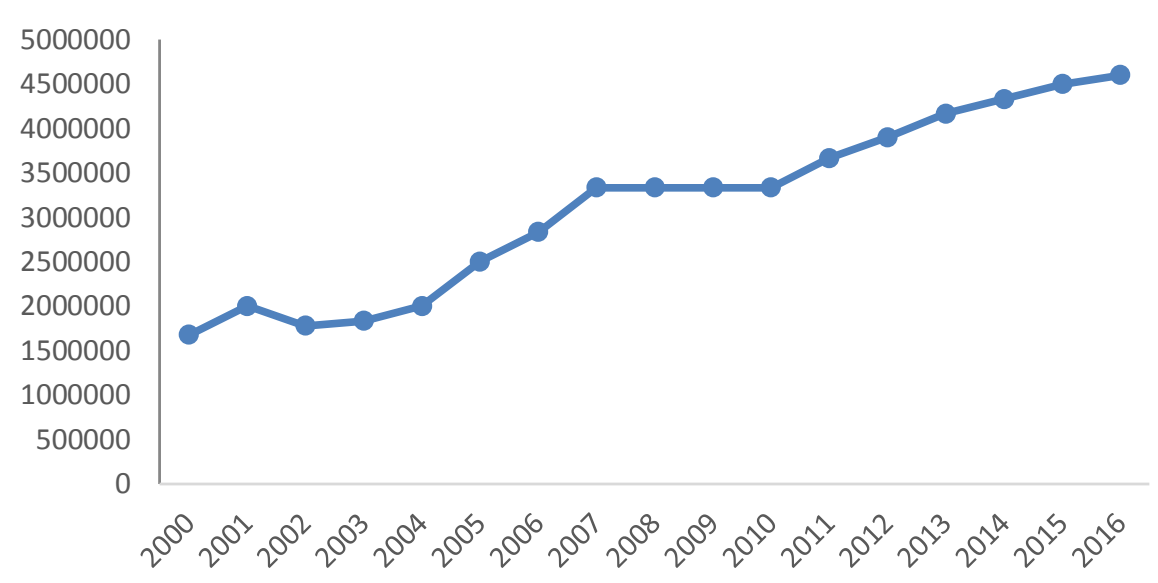

Gambar 1.

Konsumsi Kopi Indonesia

Sumber: ICO (2017)

Meningkatnya pertumbuhan usaha hilirisasi kopi dipengaruhi oleh perubahan gaya hidup masyarakat yang menjadikan kopi sebagai minuman sehari-hari (Rasyidatushshalihah, 2018; Rugian et al., 2019; Sahabuddin et al., 2019). Adanya perkembangan teknologi informasi, perubahan ekonomi, demografi, lingkungan, memicu perubahan gaya hidup dan meningkatkan daya beli masyarakat dalam mengkonsumsi sebuah produk, termasuk kopi (Sahabuddin et al., 2019).

Dengan adanya pertumbuhan tren konsumsi kopi, mendorong para wirausaha untuk memasuki bisnis UMKM kopi, khususnya di subsektor downstream yaitu restoran termasuk kafe yang menyediakan kopi (kedai kopi). Kedai kopi masa kini adalah sebuah kafe yang ditujukan untuk konsumen penikmat minuman kopi yang berbeda dengan kedai kopi pada umumnya. Konsep kedai kopi kini lebih modern dan dikelola secara profesional baik desain kedainya, maupun proses pengolahan, peracikan, penyajian, serta ragam kopi yang dijual (Rugian et al., 2019).

Meskipun demikian, mengembangkan suatu usaha yang berkelanjutan tidaklah mudah, karena wirausaha selalu menghadapi berbagai kendala eksternal dan internal. Hampir $80 \%$ perusahaan pemula gagal di tahun pertamanya, dan tingkat kegagalan usaha kecil di Indonesia mencapai angka 78\% (Rasyidatushshalihah, 2018). Hal ini disebabkan kendala yang seringkali dihadapi oleh para wirausaha UMKM baik eksternal maupun internal. Beberapa 
faktor kendala tersebut diantaranya yaitu modal, sumber daya manusia, aspek legalitas, akuntabilitas, iklim usaha, infrastruktur dan akses pasar (Bank Indonesia, 2015).

Dari beberapa faktor yang telah disebutkan, sumber daya manusia merupakan titik kritis penting dalam kinerja usaha, karena biasanya pemilik UMKM sekaligus menjadi manajer yang menjalankan usaha dan mengorganisir manusia. Maka kompetensi manajer seperti keahlian perencanaan dan berorganisasi, manajemen administrasi, dan keahlian komunikasi dibutuhkan untuk peningkatan kinerja sebuah usaha. Kompetensi kewirausahaan diperlukan oleh sebuah usaha ketika menghadapi persaingan baik di dalam negeri maupun internasional ( $\mathrm{Ng}$ dan Kee, 2013). UMKM kopi pun mengalami berbagai permasalahan pengembangan usaha akibat kompetensi wirausaha yang belum unggul, khususnya keterampilan teknis dan kemampuan manajerial (Furqon, 2019; Supriatna dan Aminah, 2016). Hal ini seringkali disebabkan karena sumber daya manusia pada usaha skala kecil masih mengandalkan pemilik atau satu orang tertentu, yang sulit mempercayai orang lain untuk membantu aktivitas usahanya (Kemenperin, 2017). Maka sebagian UMKM merasa masih memerlukan penyuluhan dan pelatihan usaha kopi dari pemerintah (Furqon 2019).

Dengan demikian, jelas bahwa kompetensi merupakan salah satu kunci kesuksesan dalam berwirausaha. Kompetensi adalah kecakapan wirausaha dalam hal kognitif, emosi, dan sosial, yang dapat dikembangkan untuk menghasilkan kinerja usaha yang unggul (Boyatzis, 2008). Oleh karena itu, studi mengenai kewirausahaan terutama kompetensinya dapat meningkatkan pemahaman fakta di lapangan dan sisi lain pengembangan penelitian bidang ekonomi di masa depan.

Dari latar belakang tersebut, perlu dilakukan studi lebih lanjut untuk memahami kompetensi apa saja yang memengaruhi kinerja UMKM kopi, agar dapat menyusun strategi pengembangan UMKM Kopi yang efektif.

\section{METODE PENELITIAN}

Metode analisis pada riset ini adalah studi pustaka, dengan cara penghimpunan dan analisis data sekunder. Data bersumber dari pustaka yang berupa artikel jurnal, dokumen pemerintah, dan artikel ilmiah lain tentang kewirausahaan dan UMKM. Beberapa tahapan penelitian yang dilaksanakan antara lain: (a) mengidentifikasi pustaka dan data sekunder yang terkait dengan fokus penelitian; (b) melakukan seleksi pustaka utama; (c) melakukan ekstraksi dan analisis data; dan (d) merumuskan serta menginterpretasi hasil analisis. Sumber data utama dalam penelitian ini dapat dilihat pada Tabel 1. 
Tabel 1. Pustaka Utama yang Terkait dengan Kompetensi Kewirausahaan Kopi

\begin{tabular}{|c|c|c|}
\hline Peneliti & Tujuan Penelitian & $\begin{array}{c}\text { Variabel Kompetensi } \\
\text { Kewirausahaan }\end{array}$ \\
\hline Aulia (2018) & $\begin{array}{l}\text { Mengamati dampak } \\
\text { kompetensi wirausaha } \\
\text { terhadap kinerja usaha } 60 \\
\text { UMK kopi }\end{array}$ & $\begin{array}{l}\text { Kemampuan konseptual, } \\
\text { kemampuan manajerial, } \\
\text { sosial, manajemen waktu, } \\
\text { dan pengambilan } \\
\text { keputusan }\end{array}$ \\
\hline Laoh et al. (2019) & $\begin{array}{l}\text { Mengkaji kompetensi SDM } \\
\text { terhadap keunggulan } \\
\text { bersaing usaha rumah kopi di } \\
\text { Manado }\end{array}$ & $\begin{array}{l}\text { Pengetahuan, } \\
\text { keterampilan, sikap, } \\
\text { konsep diri, nilai pribadi, } \\
\text { dan karakteristik pribadi }\end{array}$ \\
\hline $\begin{array}{l}\text { Rugian et al. } \\
\text { (2019) }\end{array}$ & $\begin{array}{l}\text { Mempelajari kompetensi dan } \\
\text { inovasi dari } 100 \text { pegawai } \\
\text { Starbucks, Maxx Coffee, dan } \\
\text { Excelso di Manado }\end{array}$ & $\begin{array}{l}\text { Pengetahuan, } \\
\text { keterampilan dan sikap } \\
\text { kerja }\end{array}$ \\
\hline $\begin{array}{l}\text { Sahabuddin et } \\
\text { al. (2019) }\end{array}$ & $\begin{array}{l}\text { Mengkaji hubungan } \\
\text { kompetensi wirausaha } 200 \\
\text { warung kopi di Sulawesi } \\
\text { Selatan terhadap kapabilitas } \\
\text { kinerja usahanya }\end{array}$ & $\begin{array}{l}\text { Orientasi, motivasi kerja, } \\
\text { dan komitmen } \\
\text { berwirausaha }\end{array}$ \\
\hline $\begin{array}{l}\text { Aknesia et al. } \\
\text { (2015) }\end{array}$ & $\begin{array}{l}\text { Menganalisis keunggulan } \\
\text { bersaing PT Sinar Mayang } \\
\text { Lestari untuk pengembangan } \\
\text { usaha kopinya }\end{array}$ & $\begin{array}{l}\text { Kompetensi/kemampuan } \\
\text { di bidang usahatani, } \\
\text { pasca panen, dan } \\
\text { promosi }\end{array}$ \\
\hline $\begin{array}{l}\text { Fadhil et al. } \\
\text { (2017) }\end{array}$ & $\begin{array}{l}\text { Memformulasikan strategi } \\
\text { pengembangan SDM } \\
\text { agroindustri kopi dalam } \\
\text { menghadapi persaingan } \\
\text { MEA. }\end{array}$ & $\begin{array}{l}\text { Kapabilitas dan kualitas } \\
\text { SDM }\end{array}$ \\
\hline
\end{tabular}

Metode Studi Pustaka ini difokuskan pada dua tinjauan, yakni Tinjauan Teoritis dan Tinjauan Empiris. Tinjauan Teoritis dilakukan untuk menganalisis hubungan-hubungan antara kewirausahaan dan kompetensi kewirausahaan dengan kinerja usaha berdasarkan teori yang sudah ada. Tinjauan Empiris dilakukan untuk membedah hasil-hasil penelitian terdahulu tentang kompetensi kewirausahaan di UMKM, khususnya di UMKM Kopi. Kemudian, berdasarkan kedua tinjauan tersebut dirumuskan strategi pengembangan UMKM Kopi. 


\section{HASIL DAN PEMBAHASAN}

\section{Teoritis: Kewirausahaan dan Kinerja Usaha}

Pada sebuah usaha termasuk UMKM, kompetensi wirausahanya akan sangat mempengaruhi kinerja bisnisnya. Wirausaha beserta kompetensinya merupakan sumber daya penting dan berharga dari sebuah perusahaan (Mitchelmore dan Rowley, 2010), karena kompetensi mengacu pada kualitas tindakan yang diambil oleh para wirausaha, maka secara langsung kompetensi berkaitan dengan hasil usaha. Sumber daya perusahaan adalah hal yang berharga, langka, sulit ditiru, dan tak tergantikan, yang dapat menjadi keunggulan kompetitif bagi perusahaan. Berdasarkan perspektif ini, kompetensi kewirausahaan adalah sumber daya berharga bagi perusahaan (Tehseen dan Ramayah, 2015). Kompetensi kewirausahaan merupakan salah satu kemampuan yang perlu dimiliki wirausaha dalam melaksanakan pekerjaan agar sukses. Kompetensi inilah yang membuat wirausaha dapat memulai dan mengubah bisnis mereka menjadi besar dan berkinerja baik. Kinerja usaha dapat diukur berdasarkan berbagai macam indikator, misalnya keberlangsungan usaha, peningkatan volume penjualan, pendapatan, dan keuntungan, keunggulan bersaing, pengembangan wilayah pemasaran, maupun penambahan tenaga kerja.

Kompetensi kewirausahaan ini tidak sepenuhnya terpisah dari karakteristik pribadi pengusaha, sifat, dan motivasi (Lee et al., 2016). Bird dalam Mitchelmore dan Rowley (2010) mengemukakan bahwa kompetensi kewirausahaan dideskripsikan sebagai kombinasi karakteristik individu (internal) dan faktor eksternal, seperti sifat, motif, citra diri, pengetahuan khusus, peran sosial, dan keterampilan yang menghasilkan penciptaan usaha, kelanggengan maupun pertumbuhannya.

Lee et al. (2016) mengidentifikasi terdapat lima dimensi kompetensi kewirausahaan yakni (1) Peluang yaitu kemampuan mengidentifikasi, mengembangkan dan menilai peluang; (2) Administrasi, memiliki ketrampilan administrasi dan dapat mengoperasikan perusahaan dengan baik; (3) Hubungan, yaitu kemampuan merekrut kandidat yang dapat dilatih, membangun kepercayaan dan hubungan yang sehat dengan karyawan, berkomunikasi dan mengarah pada budaya perusahaan yang baik; (4) Personal, ciri individu yang tercermin dalam perilaku wirausahawan; dan (5) Komitmen, maju dengan ketekunan sekalipun situasi yang tidak pasti. Sedangkan Ploum et al. (2018) menyarankan agar usaha dapat berkelanjutan, terdapat enam kompetensi wirausaha yang merupakan hal kunci, yaitu kompetensi manajemen dan tindakan strategis, keberagaman, berpikir sistem, normatif, berpikir jauh ke depan, dan interpersonal.

Hasil eksplorasi Robles dan Zarraga-Rodriguez (2015) pada 20 kompetensi kewirausahaan, menyimpulkan bahwa kompetensi yang relevan untuk 
kewirausahaan antara lain kompetensi menilai risiko, berinisiatif, bertanggung jawab, dinamis, orientasi pemecahan masalah, mengidentifikasi dan menganalisis informasi, berorientasi hasil, serta manajemen perubahan dan kualitas pekerjaan. Studi Rahab et al. (2016) menegaskan bahwa ketiga dimensi kompetensi inti pada sebuah perusahaan kecil, yaitu kompetensi hubungan, kompetensi adaptasi, dan kompetensi inovasi, signifikan dalam menjelaskan daya saing perusahaan. Kemudian Mitchelmore dan Rowley (2010) merangkum dari berbagai penulis bahwa berbagai keterampilan, pengetahuan, dan pengalaman, sebagai jantung dari kesuksesan wirausaha, seperti latar belakang dan pengalaman pribadi; pengaruh faktor sosio-ekonomi; kemampuan intelektual, sosial, dan manajerial; kualitas kepribadian; karakteristik perilaku; manajemen waktu, interaksi, dan komunikasi.

Hingga saat ini belum ada kesepakatan mengenai apa yang menjadi ciri unik dan khas dari kompetensi seorang wirausaha. Para peneliti sepakat bahwa kompetensi kewirausahaan merupakan kombinasi berbagai kemampuan dan karakteristik yang membuat seorang wirausaha sukses dalam lingkungan yang kompetitif, walau indikatornya dapat berbeda tergantung jenis usahanya. Kompetensi yang diperlukan untuk menjalankan sebuah perusahaan kecil berbeda dari yang dibutuhkan oleh perusahaan yang lebih besar.

\section{Empiris: Kompetensi Kewirausahaan dan UMKM}

Pemikiran-pemikiran seperti yang dikemukakan dalam kerangka teoritis di atas dapat diamati pada UMKM kopi di Indonesia. UMKM kopi yang berbentuk kafe (kedai kopi) berkembang dengan adanya peningkatan konsumsi kopi baik domestik maupun global karena adanya perubahan gaya hidup, sehingga terjadi pertumbuhan coffee shop di beberapa kota besar di Indonesia. Walau demikian kendala yang dihadapi masih banyak, termasuk kompetensi wirausaha UMKM kopi yang belum unggul. Indikasi adanya pengaruh positif kompetensi kewirausahaan terhadap kinerja usaha kedai kopi dapat ditemukan pada beberapa hasil studi (Aulia, 2018; Laoh et al., 2019; Rugian et al., 2019; Sahabuddin et al., 2019), walaupun kompetensi kewirausahaan dijelaskan dengan berbagai variabel yang berbeda oleh peneliti.

Aulia (2018) meneliti tentang dampak kompetensi wirausaha terhadap kinerja usaha UMK kedai kopi. Analisis dilakukan dengan menggunakan metode PLS, dengan sampel sejumlah 30 kedai kopi skala kecil dan 30 kedai kopi skala mikro. Hasil penelitian Aulia (2018) menyatakan bahwa kompetensi kewirausahaan mempengaruhi kinerja usaha (keuntungan dan volume penjualan) baik pada skala mikro maupun pada skala kecil. Indikator kompetensi kewirausahaan yang dapat ditingkatkan adalah kemampuan konseptual, manajerial, sosial, mengatur waktu, dan membuat keputusan.

Kemudian Sahabuddin et al. (2019) mengkaji hubungan kompetensi pada 200 wirausaha terhadap kapabilitas kinerja usaha warung kopi di Sulawesi 
Selatan, dengan menggunakan SEM. Kompetensi kewirausahaan pada studi ini terdiri dari variabel orientasi kewirausahaan, komitmen berwirausaha, serta motivasi. Hasil analisis menunjukkan bahwa orientasi kewirausahaan secara nyata mempengaruhi kinerja usaha. Orientasi ini merupakan titik ungkit yang memberi dorongan pada wirausaha warung kopi untuk mengembangkan dan menaikkan kinerja usahanya. Sahabuddin et al. (2019) menemukan bahwa motivasi kerja tidak berpengaruh secara nyata terhadap kinerja usaha, akibat motivasi kerja secara umum belum terbangun. Hal ini disebabkan warung kopi relatif merupakan usaha kecil, sehingga dalam menjalankan usaha tersebut umumnya mereka masih menggunakan manajemen yang relatif tradisional. Sebagian besar pemilik usaha sekaligus berperan sebagai kasir, pelayan, maupun manajer. Walau demikian, motivasi kerja dapat mempengaruhi kinerja usaha secara tidak langsung melalui komitmen berwirausaha. Komitmen berwirausaha secara nyata berdampak terhadap kinerja usaha, dengan adanya komitmen yang tinggi akan mendorong terciptanya kemampuan wirausaha untuk menjadi kreatif dan inovatif sehingga ia akan menemukan sesuatu hal yang berbeda dari yang pernah ada.

Laoh et al. (2019) dan Rugian et al. (2019) mengkaji kompetensi SDM pada keunggulan daya saing usaha rumah kopi di Manado, Sulawesi Selatan. Rugian et al. (2019) mencoba mempelajari kompetensi dan inovasi dari 100 pegawai Starbucks, Maxx Coffee, dan Excelso. Hasil analisis penelitian membuktikan bahwa keunggulan kompetisi signifikan dipengaruhi oleh kompetensi maupun inovasi SDM. Kompetensi yang harus ditingkatkan di rumah kopi antara lain pengetahuan, skill, dan sikap kerja. Mendukung studi ini, Laoh et al. (2019) menyampaikan bahwa kompetensi SDM dan karakteristik individu mempengaruhi kinerja pegawai rumah kopi. Kompetensi tersebut diukur melalui pengetahuan, keterampilan, sikap, konsep diri, nilai pribadi, dan karakteristik pribadi. Untuk itu, perusahaan menyimpulkan bahwa ke depan mereka akan mengembangkan dan memahami kompetensi kewirausahaan dengan merekrut karyawan yang berkompeten agar dapat lebih bersaing dibandingkan rumah kopi modern lainnya, serta peningkatan kompetensi melalui pelatihan (Laoh et al., 2019; Rugian et al., 2019). Hal ini sejalan dengan strategi pengembangan bisnis kopi spesialti Indonesia yang sedang berkembang di Indonesia akibat adanya peningkatan konsumsi kopi, namun kemampuan SDM pada pengolahan kopi rendah dan sistem manajerial tidak terorganisir dengan baik. Aknesia et al. (2015) menyarankan agar dilakukan peningkatan kompetensi di bidang usahatani, pasca panen, dan promosi, melalui pelatihan terkait industri kopi spesialti, seperti grading, roasting dan pelatihan barista. Tidak jauh berbeda, dalam rangka memperkuat daya saing di dunia internasional khususnya Masyarakat Ekonomi ASEAN, maka Fadhil et al. (2017) menyarankan beberapa strategi pengembangan sumber daya manusia agroindustri kopi Gayo, diantaranya dengan mengembangkan kualitas serta 
kompetensi SDM melalui pendidikan, ilmu pengetahuan, dan teknologi. Karena kompetensi SDM agroindustri kopi Gayo mencerminkan karakteristik, pengetahuan, keterampilan, perilaku, serta motivasi individu, maka kompetensi ini erat berhubungan dengan keberhasilan wirausaha dalam menjalankan usahanya.

Secara umum, UKM di Indonesia membutuhkan sejumlah kompetensi penting terutama kemampuan bersaing, memberikan kepuasan kepada konsumen, dan motivasi untuk bertahan dan berkembang (Wulani et al. 2019). Para wirausaha membutuhkan kompetensi yang berkaitan dengan menjalankan fungsi manajemen dan peningkatan kualitas produk. Sebagai upaya meningkatkan kemampuan wirausaha UKM, Kementerian Koperasi dan UMKM serta sektor swasta, telah melakukan berbagai pelatihan untuk wirausaha. Salah satu hal penting dalam kegiatan pelatihan ini adalah bahwa pemilik UKM dapat berbagi informasi tentang kunci keberhasilan dan kegiatan promosi yang dilakukan oleh pemerintah.

\section{Strategi Pengembangan UMKM Kopi}

Berdasarkan hasil penelitian, secara umum kinerja usaha dipengaruhi oleh kompetensi kewirausahaan. Kompetensi kewirausahaan dibentuk dari faktor internal maupun faktor eksternal, sehingga kombinasi kedua faktor tersebut tersebut diperlukan oleh seorang wirausaha untuk meningkatkan kinerja usaha. Hasil analisis dari studi pustaka menemukan bahwa variabel-variabel kompetensi wirausaha di bidang kopi yang paling menonjol antara lain kemampuan konseptual, keterampilan dan karakteristik individu terutama motivasi.

Secara umum, dengan adanya permasalahan pada kemampuan manajerial dan teknis seperti pengolahan kopi maka strategi yang dapat dibangun antara lain adalah meningkatkan kapabilitas wirausaha UMKM kopi melalui berbagai pelatihan teknis, misalnya pelatihan roasting, barista, dan pengolahan pasca panen kopi lainnya. Salah satu yang dapat dilakukan adalah melalui sekolah kopi yang sedang berkembang saat ini.

Untuk membangun karakteristik individu yang akan meningkatkan kompetensi, pemerintah dapat memberikan penyuluhan mengenai kewirausahaan misalnya motivasi kerja. Selain itu, kemampuan manajerial wirausaha UMKM terutama manajemen pemasaran pun perlu ditingkatkan. 


\section{SIMPULAN DAN SARAN}

\section{Simpulan}

Berdasarkan studi teoritis dan empiris yang dilakukan, maka simpulan yang dapat diambil adalah ditemukannya pengaruh kompetensi kewirausahaan terhadap kinerja usaha UMKM kopi di Indonesia. Secara umum, variabel yang mempengaruhi kompetensi kewirausahaan UMKM kopi adalah kemampuan konseptual, keterampilan, dan karakteristik individu. Sehingga, merujuk pada teori dan hasil-hasil penelitian yang terkait, untuk mengembangkan UMKM kopi diperlukan peningkatan kompetensi kewirausahaan.

\section{Saran}

Dengan pemahaman bahwa kompetensi kewirausahaan merupakan sumberdaya bernilai bagi sebuah usaha, maka kompetensi kewirausahaan akan menjadi keunggulan kompetitif bagi wirausaha, yang akan membuat usahanya berkinerja baik. Maka, dalam rangka mengembangkan kinerja usaha UMKM kopi Indonesia, strategi yang dapat dilakukan adalah dengan peningkatan kapabilitas wirausaha UMKM kopi baik di bidang teknis dan manajemen.

Kemampuan konseptual dan keterampilan berwirausaha dapat ditingkatkan melalui pelatihan pengolahan kopi, roasting, barista, dan manajemen pemasaran. Sedangkan untuk membangun karakteristik individu yang terkait kompetensi kewirausahaan, penyuluhan mengenai motivasi dan kewirausahaan perlu dilakukan. Untuk itu diperlukan dukungan dari berbagai pemangku kepentingan seperti pemerintah dan swasta untuk memfasilitasi program dan kegiatan yang dapat mendorong peningkatan kompetensi kewirausahaan UMKM kopi.

\section{DAFTAR PUSTAKA}

Aknesia, V., Daryanto A., and Kirbrandoko. 2015. Business Development Strategy for Specialty Coffee. Indonesian Journal of Business and Entrepreneurship 1(1):12-22.

Aulia, M. R. 2018. Pengaruh kompetensi kewirausahaan terhadap kinerja usaha kedai kopi skala mikro dan kecil di kota Bogor. Institut Pertanian Bogor.

Bank Indonesia. 2015. Profil Bisnis Usaha Mikro, Kecil Dan Menengah (UMKM). Jakarta: Bank Indonesia.

Boyatzis, R.E. 2008. Competencies in the 21st century. Journal of Management Development 27(1):5-12.

Fadhil, R., Maarif, M. S., Bantacut, T., dan Hermawan, A. 2017. Model Strategi Pengembangan Sumber Daya Manusia Agroindustri Kopi Gayo dalam

126 | Anggita Tresliyana Suryana; Burhanuddin; Pengaruh Kompetensi... 
Menghadapi Masyarakat Ekonomi ASEAN. Jurnal Manajemen Teknologi 16(2):141-155.

Furqon, M. 2019. Analisis Strategis Pengembangan Berbasis Ekonomi Lokal pada UMKM Kopi Muria di Kabupaten Kudus. Universitas Diponegoro.

ICO. 2017. Konsumsi Kopi Indonesia Tahun 2000-2016.

KEMENKOP. 2018. Perkembangan Data Usaha Mikro, Kecil, Menengah (UMKM)

Dan Usaha Besar (UB). Jakarta: Kementerian Koperasi dan Usaha Mikro, Kecil, dan Menengah.

Kemenperin. 2014. Kebijakan Pemerintah Dalam Mendorong Industrialisasi Kopi, Kakao, Dan Teh Di Indonesia. Jakarta: Kementerian Perindustrian.

Kemenperin. 2017. Peluang Usaha IKM Kopi. Jakarta: Ditjen Industri Kecil dan Menengah, Kementerian Perindustrian RI.

Laoh, J., Sendow, G. M., dan Uhing, Y. 2019. Pengaruh Karakteristik Individu dan Kompetensi Sumber Daya Manusia Terhadap Kinerja Karyawan Pada Usaha Rumah Kopi di Manado. Jurnal EMBA 7(4):4620-4629.

Lee, H., Lee, J., Shim, K., and Lee, H. 2016. Entrepreneurial characteristics: A systematic literature review. PACIS 2016 Proceedings

Mitchelmore, S. and Rowley, J. 2010. Entrepreneurial competencies: A literature review and development agenda. International Journal of Entrepreneurial Behaviour \& Research 16(2):92-111.

$\mathrm{Ng}$, H. S. and Kee, D. M. H. 2013. Effect of entrepreneurial competencies on firm performance under the influence of organizational culture. Life Science Journal 10(4):2459-2466.

Ploum, L., Blok, V., Lans, T., and Omta, O. 2018. Toward a Validated Competence Framework for Sustainable Entrepreneurship. Organization and Environment 31(2):113-132.

Rahab, R., Anwar, N., and Priyono, R. E. 2016. Effect of Core Competence on Sustainable Competitive Advantages of Batik Banyumas Small and Medium Enterprises. Journal of Comparative International Management 19(1):27-45.

Rasyidatushshalihah, S. 2018. Perancangan Strategi dan Pengukuran Kinerja UMKM dengan Pendekatan Balanced Scorecard (Studi Kasus Rozen Specialty Corner Bogor). Institut Pertanian Bogor.

Robles, L. and Zarraga-Rodriguez, M. 2015. Key Competencies for Entrepreneurship. Procedia Economics and Finance 23 (2015) 828 - 832. Rugian, M. S., Tewal, B., dan Taroreh, R. N. 2019. Pengaruh Kompetensi Sumber Daya Manusia dan Inovasi Terhadap Keunggulan Bersaing Rumah Kopi Modern di Manado. Jurnal EMBA 7(4):5943-5952.

Sahabuddin, R., Arief, A. A., dan Djufri, M. 2019. Analisis Kompetensi Kewirausahaan Pengusaha Warung Kopi Terhadap Kapabilitas Kinerja Usaha di Sulawesi Selatan. Prosiding Seminar Nasional LP2M UNM - 2019 
"Peran Penelitian dalam Menunjang Percepatan Pembangunan Berkelanjutan di Indonesia," Makassar: Universitas Negeri Makassar, hal. 59-69.

Supriatna, S. dan Aminah, M. 2016. Analisis Strategi Pengembangan Usaha Kopi Luwak (Studi Kasus UMKM Careuh Coffee Rancabali-Ciwidey, Bandung). Jurnal Manajemen dan Organisasi 5(3):227.

Tehseen, S. and Ramayah, T. 2015. Entrepreneurial Competencies and SMEs Business Success: The Contingent Role of External Integration. Mediterranean Journal of Social Sciences 6(1):50-61.

Wulani, F., Lindawati, T., Putro, A. J. W. T., and Suhartatik, A. 2019. Scale Development of Entrepreneurial Competency of SME Owner in Indonesia. Academy of Entrepreneurship Journal 25(4):1-12. 